The effectiveness of Pantawid Pamilyang Pilipino Program (4P's) in the education and welfare of selected pupil recipient in Rosario, Batangas: Basis for policy improvement

Ramos, Analyn D.

Department of Education, Philippines (analyn.ramos008@deped.gov.ph)

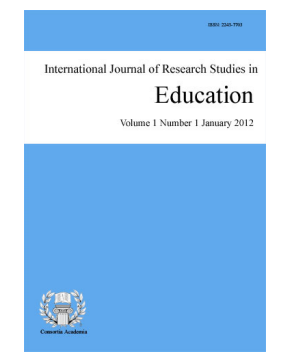

ISSN: 2243-7703 Online ISSN: 2243-7711

OPEN ACCESS

\title{
Abstract
}

This study assessed the extent of effectiveness of Pantawid Pamilyang Pilipino Program (4P's) on education and welfare of selected pupil recipients in Rosario, Batangas. The status of effectiveness is measured using the health/nutritional and educational welfare. Whereas, different constraints encountered by recipients were measured and identified. The research locale of this study included selected grade V and VI pupils and parents-respondents in 3 big public elementary schools in Rosario East District and 3 big public elementary schools in Rosario West District during the school year 2020-2021. The descriptive method of research was employed in this study. It also focused on the policy improvement to be proposed to enhance the program for the benefit of pupil recipients. Data obtained were statistically tested with the use of weighted mean, T-test, and Pearson Product Moment of Correlation Coefficient. The result of the study showed that there is a high significant difference on the assessment of pupils and parent-respondents on the effectiveness of 4P's. Furthermore, there is a high significant difference between the assessment of student-respondents and parent-respondents on the constraints of effectiveness of 4P's. There is a high significant relationship between the health/nutritional and educational welfare and constraints on the effectiveness of the program. Negative correlation is obtained. It is recommended that the Department of Social Welfare and Development (DSWD) must enhance 4P's in terms of benefits of pupil recipients. DSWD must increase cash grants for educational welfare of pupil recipients and control the family educational expenditure by coordinating with teachers.

Keywords: Pantawid Pamilyang Pilipino Program (4P's); effectiveness; recipients; cash grant; policy improvement 


\section{The effectiveness of Pantawid Pamilyang Pilipino Program (4P's) in the education and welfare of selected pupil recipient in Rosario, Batangas: Basis for policy improvement}

\section{Introduction}

All parents want the best for their children. They want their children to finish their studies. Unfortunately, many poor families cannot provide for the education of their children. Some families can only afford one meal a day and they cannot even send their children to school. The Philippines has been battling against poverty for over several years. Because poverty continues to worsen every now and then, the government has its own strategies and policy adaptations to combat the serious issue of poverty. Poor families in the Philippines have six or more members, with greater numbers of younger and older dependents. In most poor families, the head of household has only an elementary education or below. These families have few or no assets and minimal access to electricity, water sources and toilet facilities. They also have limited access to health and education services. Among Philippine citizens, the poor are most vulnerable to financial and price shocks and natural disasters. Often their efforts to cope with these shocks and make up for lost livelihoods and income result in deeper levels of indebtedness.

The latest campaign against poverty applied in other countries in the world is the Conditional Cash Transfer Program (CCT). South American countries like Brazil, Columbia and Mexico are the first countries to apply the said approach. In the Philippines, the CCT was adopted and applied. It has been referred to as Pantawid Pamilyang Pilipino Program (4P's). Santiago (2012) created and approved the Senate Bill No. 3412 or the Pantawid Pamilyang Pilipino Program Act of 2009. The bill aims to institutionalize the program by formally making it the National Conditional Fund Transfer Program. The 4P's also helps the Philippine government fulfill its commitment to the Millennium Development Goals (MDGs) - specifically in eradicating extreme poverty and hunger, in achieving universal primary education, in promoting gender equality, in reducing child mortality, and in improving maternal health care. The program is currently implemented by the Department of Social Welfare and Development (DSWD).

The idea behind CCT Pantawid Pamilyang Pilipino Pilipino Program is that poor families are given a subsidy if they agree to certain conditions: keep their children in school, receive health care during and after pregnancy, and agree to have children immunized, be subjected to periodic checkups, and be monitored for growth. The aim is to "increase the productivity of the poor". 4P's operates in many different provinces covering municipalities and key cities. Six thousand a year or five hundred per month per household for health and nutrition expenses and three thousand for one school year (10 months) or three hundred per month per child for educational expenses are allotted to qualified recipients. These cash grants are distributed to the household-beneficiaries through the Landbank of the Philippines or, if not feasible, through alternate payment schemes. Subsidies can be received by the household-beneficiaries if pregnant women availed pre and post- natal care and attended during the child birth by trained professional.

Parents and guardians attend family development sessions which include topics on responsible parenting, health and nutrition. Children aged 0-5 receive regular preventive health check-ups and vaccines. Children aged 6-14 receive deworming pills twice a year. Every child beneficiary ages 3-18 enrolled in a school maintains an attendance of at least $85 \%$ class days every month. Households whose economic conditions are equal to or below the provincial poverty threshold and who agree to meet the conditions specified in the program are eligible as beneficiaries. Many good benefits rose from the implementation of Pantawid Pamilyang Pilipino Program (4P's) such as increase in enrollment in public schools, alleviation of malnourished children and almost out of school youth. The Department of Education and DSWD saw the importance of the program. The Local Government assessed that the program contributes a lot in education and welfare of the pupil recipients. 
The program is currently covering 255 municipalities and 15 key cities in 45 provinces, serving 700,000 households nationwide. In many different public schools, the number of 4P's recipients is highly evident. They grow in population considered as the leading group assisted by the government in terms of education. They are regularly monitored in terms of their attendance, health, and condition in school. But then, not all pupil recipients are meeting the expected condition of the program. Some of the negative circumstances are immediately reported to the office of the local government or DSWD. On the other hand, the government needs to address solutions to different problems on the implementation of the program. DSWD created the Grievance Redress System (GRS). This system collates complaints directed to the program or to beneficiaries. The system alone has delisted more than 77,000 beneficiaries. They were delisted because of the following reasons: they did not follow the required tasks set by the department - such as regular health consultations, pre- and post-pregnancy care for mothers - and failed to encourage their children to attend school for a minimum number of times.

The nature, scope, observation, and extent of effectiveness of Pantawid Pamilyang Pilipino Program (4P's) to the benefit of the pupils as implemented by the government is determined to an extent to the local government, household recipients and teacher's reaction toward these. Rosario is classified as a second-class municipality having a large population and number of poor families. Farming is the common source of livelihood for families. It has 48 barangays and each barangay has an elementary school. Schools are grouped in East and West District. Education is really a great intention of each humble parent for his children. Sending in school and satisfying the needs of the children are some common problems of parents. The existence of the program that will assist the education and welfare of the pupils gave hope to the poor families in Rosario.

Pantawid Pamilyang Pilipino Program (4P's) is currently helping 5,204 4P's household recipients. All elementary schools in the municipality have 4P's recipients. The program is a great help to the families because the cash assistance that they are receiving sustains the financial needs of the children in school. Since parent-recipients are highly involved in this study, they have encountered different problems as well. Few of them are complaining about the delayed release of cash allowance. The use of ATM is a problem for some of the recipients, so they need assistance every time they need to get cash. In the experience of some teachers, some pupil recipients are not submitting projects on time and not paying authorized contributions until its due date.

In this regard, Rosario District in partnership with the DSWD is working hand in hand to supervise and monitor each recipient of the Pantawid Pamilyang Pilipino Program. Hence, this study intends to evaluate the extent of effectiveness of the said program to the education and welfare of pupil recipients. The result of this study can serve as a basis for the improvement of the program. The Department of Social Welfare and Development (DSWD) can generate some policy interventions on how to enhance and expand the program. The department can expand the year of coverage of educational assistance to each pupil-recipient to assure better results. School as a community as well as parents can draw clear solutions on constraints that arise from this study. This study reveals the value of responsibility on the part of the parents to meet the conditions of the program. The researcher recognizes the great importance of Pantawid Pamilyang Pilipino Program (4P's) in the education and welfare of each pupil so he will encourage every pupil to attend school, participate and be productive in return to the assistance received from the government.

\section{Literature review}

The CCT (Conditional Cash Transfer) programs in other countries have favorable education outcomes but others may not. In the Philippines, they have a computer system available to monitor the compliance and conditionalities among beneficiaries if they are attending classes and in health centers. Therefore, it clearly makes sense from a poverty reduction point of view to make that additional investment on the education of the child. A high school graduate will have more employment opportunities and higher pay. If the program aims only for graduation in the elementary level, and does not provide an effective exit strategy, the possible returns are very minimal to matter. 
Given the same budget, recipients proposed that deepening the program would yield better human development outcomes rather than expanding it to cover as many poor people as possible. Instead of increasing the number of beneficiary families, they recommend the expansion of the program by providing longer assistance to current beneficiaries to ensure that their children finish high school. This would mean extending coverage to up to 16 or 18 years of age (considering Kto12) to enable the CCT children to finish high school and increasing the period of coverage from 5 to 10 years or even longer. Due to the financial burden of supporting till the child finishes high school, it is also worthwhile to consider starting the education support at a higher grade. While it intends to ensure universal access to primary education, the program could also have a better impact if it were to target the five percent of the 7- to 12-years old who are not attending school. This would mean prioritizing children of indigenous people and other population subgroups who live far from public schools and street children to ensure that they attend elementary school.

Ruiz et al. (2013) stated that in selected areas in the Philippines, praise for Pantawid Pamiliya and brought to bear three other issues. First, family beneficiaries receive the grant for at most five years if they comply with the conditionalities. This maximum five-year support could mean that a child who was six years old at the time that the family first received the benefit may only complete Grade 5 by the time the family exits from the program. If the program seeks not only to improve school attendance but improve at least elementary school graduation rates, then coverage could be extended to address the fact that some $23 \%$ of 14 -year-old students are still in elementary school when they should be in high school. Second, since community health volunteers have been mandated to take on additional activities under Pantawid Pamilyang Pilipino Program, health administrators stressed that there is insufficient, if any, allowance for transport or equipment for their outreach and verification work, which is above and beyond the terms of their original job description. Currently, designated project staff is provided such allowance but not frontline community health workers. Addressing this concern may increase health care service delivery coordination efforts and desired health outcomes that the program aims to improve. Third and last, parent beneficiaries shared that they especially find programs on entrepreneurship of enormous value and expressed interest for a wider range of sessions on skills training so that they could diversify other means of earning livelihoods. Overall, Pantawid Pamilyang Pilipino Program is on track to achieve its objectives of promoting investments in the health and education of children while providing immediate financial support to poor families as highlighted in a recent impact.

According to the Center of Global Action in University of California (2010), adding conditionality or directing the cash transfers to mothers did not increase the program's impact on student attendance or school enrolment. This is likely because the program was framed as an educational support program and perceived as an endorsement of the local schools, since headmasters were responsible for enrolling families. Overall, the results of the recipient experiences suggest that in some contexts unconditional but labelled transfers targeted at poor communities can provide parents with the small nudge necessary to increase attendance. This nudge is relatively inexpensive, due to both small transfers per child and small administrative costs.

Mella et al. (2011) states that 4Ps also have its disadvantages that may encumber its helpful benefits. One of the most crucial characteristics of the 4Ps and other CCT programs implemented in other countries is its being a 'demand-side' intervention instead of being a 'supply-side' intervention. That is, to be considered as a beneficiary of the program, one must concede with the government's demands and conditionalities. This is remarkably notable in the conditions concerning education and health services where the beneficiaries are being brought into the education and health services system instead of expanding the education and health systems to reach them. Furthermore, as previously mentioned, poverty in the country is not only caused by the lack of economic resources but also because of socio-economic and political factors that prevent the equality and distribution of resources. Although the $4 \mathrm{Ps}$ aims to provide the poor with the education which is, otherwise, inaccessible, it does not directly answer the socio-economic and political problems which are the primary cause of poverty. In the case of the 4Ps in the Philippines, it does not answer the issues regarding the political and economic elite families. And poverty can only be totally alleviated if there are programs that could target its roots.

136 Consortia Academia Publishing (A partner of Network of Professional Researchers and Educators) 
Cuesta (2007) mentions that 4Ps will also encounter some difficulties in achieving support from the other social classes, mainly because it does not benefit middle-income groups which have also been steadily affected by limited universal services and decreases in employment. These middle-income groups are also suffering from issues of poverty and limited access to educational and health benefits but are not included in the target population of the 4Ps. The 4Ps is programmed to help only the extremely poor. Another major disadvantage of the 4Ps implementation is that it requires a huge amount of finance which we do not have at the present. The 4Ps is a loan driven program, wherein much of the funds constituting the conditional cash grants given to beneficiaries are generated from loans abroad, particularly from the United States. Arguments against the 4Ps point out that despite the large amounts of financial resources needed to implement the program, it does not generate guaranteed returns to the economy as much as infrastructure.

They also mentioned that the 4Ps is a good example of strengthening the government's capability of distributing the country's resources to those who are extremely in need. It is undeniable that there are many poor households that benefit from the said program, and that the program covers the basic needs that otherwise would go unmet. Likewise, the government's effort in making the country's educational and health services system inclusive is a huge step towards social mobility and equality. The researchers feel strongly about the 4Ps' principle that well-fed and educated citizens are imperative for a productive country and society. However, it is also undeniable that the 4Ps, as well as the other CCT programs being implemented in other countries, is not the perfect solution. There are many insufficiencies that the program might face in the long run of its implementation. In the Philippines, the 4Ps will certainly need further revisions and studies in the future. Nevertheless, the researchers believe that for any government program to succeed, the government and the citizens must arrive at a peaceful consensus. The government's duty is to ensure that the people's needs are provided, and their rights are protected. The citizens, in return, must use their full capacity to be productive and help the country. The researcher believes that the implementation of the 4Ps is a good example of the concurring responsibilities of the government and the citizens.

This study determined the extent of effectiveness of Pantawid Pamilyang Pilipino Program (4P's) on the education and welfare of the selected pupil recipients in Rosario, Batangas. Specifically, it answered the following questions.

1. To what extent is the effectiveness of Pantawid Pamilyang Pilipino Program (4P's) as perceived by the parents and pupils in terms of: 1.1 health/nutrition and 1.2 educational assistance?

2. What are the constraints encountered by recipients in the Pantawid Pamilyang Pilipino Program (4P's) in terms of their pupil's education and welfare?

3. Is there a significant difference in the assessment of respondents regarding the effectiveness of the program on the education and welfare of the pupils?

4. Based on the findings of the study, what policy improvement can be proposed to enhance the education and welfare of the pupils in Rosario, Batangas through Pantawid Pamilyang Pilipino Program (4P's)?

\section{Methodology}

The descriptive method of research was employed in this study. The researcher in this study assessed the effectiveness of Pantawid Pamilyang Pilipino Program on the education and welfare of pupil recipients. It focuses on the description of the above program. The population of the study consisted of parents and pupil 4P's recipients in selected schools of Rosario, Batangas during the school year 2020-2021. Rosario East Central School, Alupay Elementary School and Bagong Pook Elementary School were the selected schools in Rosario East District. They are composed of 416 total parents and pupil- respondents. While in Rosario West District, Rosario West Central School, Itlugan Elementary School and Bulihan Elementary School were the respondent-schools with 390 total respondents. The study had 806 total respondents from Rosario, Batangas. 
In this study, the researcher used a questionnaire to gather data. This questionnaire is a written instrument that contains a series of responses to relevant questions or items that attempt to collect information from an unidentified group of respondents. The questionnaire was divided into two parts: Part one (1) dealt with the effectiveness of Pantawid Pamilyang Pilipino Program, and Part two (2) for the problems encountered by the household recipients of the program. The survey questionnaire for parents and pupils were formulated in the mother tongue to be more comprehensible. The researcher found these methods useful and effective.

The data for the study were gathered from the sample consisting of 403 parents and 403 pupils who were 4P's recipients in Rosario, Batangas Province for school year 2020-2021. The questionnaire was reproduced according to the actual number of respondents in this study. However, before the actual administration of the questionnaire, the researcher asked permission from the office of the Schools Division Superintendent of Batangas Province through channels for the distribution of the questionnaire to selected respondents in Rosario, Batangas.

Upon the approval of the Schools Division Superintendent, arrangement with school heads and teachers in selected schools in Rosario, Batangas, was conducted. Survey instruments were given to the assigned 4P's coordinator in respective schools or guidance teacher. The survey was conducted personally in all the respondent schools. Survey questionnaires were labeled accordingly intended for pupils and parents for the easy retrieval purposes. All instruments were retrieved after two days. Additional data was collected from the office of the Department of Social Welfare and Development in the said municipality through an interview. Municipal 4P's coordinator was interviewed to gather data related to different problems they had encountered about the program as well as the complaints of the recipients to their office.

\section{Tables and figures}

Table 1.1

Effectiveness of Pantawid Pamilyang Pilipino program in terms of health/nutritional welfare

\begin{tabular}{|c|c|c|c|c|c|c|}
\hline \multirow{2}{*}{$\begin{array}{c}\text { Item } \\
\text { Ang programa ay epektibo sapagkat may... }\end{array}$} & \multicolumn{3}{|c|}{ Pupils } & \multicolumn{3}{|c|}{ Parents } \\
\hline & WM & VI & $\mathrm{R}$ & WM & VI & $\mathrm{R}$ \\
\hline $\begin{array}{l}\text { 1. probisyon ng libreng konsultasyon bago at pagkatapos } \\
\text { makapanganak ang isang buntis }\end{array}$ & 3.93 & $\mathrm{~B}$ & 5 & 4.37 & LB & 4 \\
\hline $\begin{array}{l}\text { 2. pagtuturo ng mga kaalaman ukol sa kalusugan at } \\
\text { nutrisyon ng bawat pamilya sa pamamagitan ng Family } \\
\text { Development Sessions (FDS) }\end{array}$ & 4.57 & LB & 1 & 4.50 & LB & 3 \\
\hline $\begin{array}{l}\text { 3. regular na health check-ups at pagbabakuna sa mga } \\
\text { batang edad } 0-5\end{array}$ & 4.28 & LB & 3 & 4.52 & LB & 2 \\
\hline 4. pagpupurga ng mga batang may edad na 6-14 & 4.39 & LB & 2 & 4.36 & LB & 5 \\
\hline $\begin{array}{l}\text { 5. pagbibigay ng (Php500 kada kabahayan) kada buwan } \\
\text { para sa kalusugan at nutrisyon }\end{array}$ & 4.16 & $\mathrm{~B}$ & 4 & 4.53 & LB & 1 \\
\hline Composite Mean & 4.26 & LB & & 4.45 & LB & \\
\hline
\end{tabular}

Based on the table presented, the item "pagtuturo ng mga kaalaman ukol sa kalusugan at nutrisyon ng bawat pamilya sa pamamagitan ng Family Development Sessions (FDS)" got the highest weighted mean as assessed by the pupils with a value of 4.57 and a verbal interpretation of "Lubhang Napakabisa" while the item "pagbibigay ng (Php500 kada kabahayan) kada buwan para sa kalusugan at nutrisyon" got the highest weighted mean of 4.53 and a verbal interpretation of "Lubhang Napakabisa" as assessed by parents of the pupils benefiting from the 4P's. On the otherhand the item "probisyon ng libreng konsultasyon bago at pagkatapos makapanganak ang isang buntis" got the lowest weighted mean of 3.93 and a verbal interpretation of "Napakabisa" as assessed by the pupils while the item "pagpupurga ng mga batang may edad na 6-14" got the lowest weighted mean of 4.36 with a verbal interpretation of "Lubhang Napakabisa" as assessed by the parents. 
The result reveals a variation between the responses of pupils benefiting from the program and their parents. This can be attributed to the different experiences of parents and pupils. Parents practically see the value of the cash grant not only for the health and nutrition of the beneficiaries in the family, but they can also use it to support other necessities in the family. Regular allowance is a big help for the parents. On the contrary, pupil's perception differs from their parents because they are young, and they only see the overall importance of Family Development Session (FDS) not only in gaining information about health/nutrition but it touches and changes the family holistically.

Based on observations, the parent who understands the overall responsibilities of the program, knows how the right parenthood through the Family Development Session (FDS), they are responding to the health and educational needs of their children on time. Unlike the families who are always just after the money or cash grant without prioritizing the needs of their children. According to the study of Zarsuelo, et.al (2015), that Pantawid Pamilyang Pilipino Program (4P's) is successful in meeting one of its objectives which is investing in human capital through good health. Through the program's cash grant and health care commitments, maternal knowledge and nutritional status of 4P's mothers/guardians and their children were better in terms of nutritional status. This might be due to approaches in Family Development Session (FDS) and other knowledge sources.

The pupil's perception about "probisyon ng libreng konsultasyon bago at pagkatapos makapanganak ang isang buntis" is the least in effectiveness maybe because the majority of the household mothers are not pregnant. So, they did not observe their mother in that condition. While parents' perception about "pagpupurga ng mga batang may edad na 6-14" is the least effective because some of the parents have negative views about deworming. This could imply that the parents were not well oriented about the importance of deworming to the health and nutrition of their children. Number of parents still has an uncivilized mentality.

Based on the documentation of "Faylon Ngayon" (2015), some of the 4P's recipients who received regular cash grant (PhP500) are using this in health and nutrition of their children. On the other hand, some parents used the money in gambling and buying liquor. Irresponsible parents sometimes turned in pawning the ATM. While some of the parents claimed that the 500 cash grant for health and nutrition was really a great help in keeping their children healthy. Educating parents through Family Development Sessions about parenting is one of the best efforts that the program gives. Since this opportunity opens the mind of the parents on how they raise their family. Meanwhile, table 1.2 reflects the separate assessment of pupils benefiting from the Pantawid Pamilyang Pilipino program and their parents on the effectiveness of the said program on their educational welfare.

\section{Table 1.2}

Effectiveness of Pantawid Pamilyang Pilipino Program in terms of Educational Welfare

\begin{tabular}{|c|c|c|c|c|c|c|}
\hline \multirow{2}{*}{$\begin{array}{c}\text { Item } \\
\text { Ang programa ay epektibo sapagkat may.. }\end{array}$} & \multicolumn{3}{|c|}{ Pupils } & \multicolumn{3}{|c|}{ Parents } \\
\hline & WM & VI & $\mathrm{R}$ & WM & VI & $\mathrm{R}$ \\
\hline $\begin{array}{l}\text { 1. probisyon sa pag-aaral ang mga batang may edad na } \\
\text { 3-18 }\end{array}$ & 3.86 & B & 5 & 4.54 & LB & 1 \\
\hline $\begin{array}{l}\text { 2. kondisyon na } 85 \% \text { attendance ang mga mag-aaral sa loob } \\
\text { ng isang buwan }\end{array}$ & 4.21 & LB & 2 & 4.42 & LB & 2.5 \\
\hline $\begin{array}{l}\text { 3. pagtugon sa authorized contribution at iba pang bayarin } \\
\text { sa paaralan sa tamang panahon }\end{array}$ & 4.04 & B & 3 & 4.35 & LB & 5 \\
\hline 4. pagtugon sa mga gawain sa klase at sa paaralan & 4.02 & $\mathrm{~B}$ & 4 & 4.38 & LB & 4 \\
\hline 5. pagbibigay ng Php300 kada isang mag-aaral kada buwan & 4.33 & LB & 1 & 4.42 & LB & 2.5 \\
\hline Composite Mean & 4.09 & $\mathrm{~B}$ & & 4.42 & LB & \\
\hline
\end{tabular}

Legend: W - Weighted Mean, VI- Verbal interpretation, and R - Rank.

Scale: 4.20 - 5.00 Lubhang Napakabisa (LB), 1.80 - 2.59 Kaunti ang Bisa (KNB), 3.40 - 4.19 Napakabisa (B), 1.00 - 1.79 Lubhang Kaunti ang Bisa (LNB), and 2.60 - 3.39 Katamtaman ang Bisa (KB).

The table shows that the item "pagbibigay ng Php300 kada isang mag-aaral kada buwan" got the highest weighted mean of 4.33 and and a verbal interpretation of "Lubhang napakabisa" as assessed by the pupil-respondents. The item "probisyon sa pag-aaral ang mga batang may edad 3-18" got the highest weighted mean of 4.54 and a verbal interpretation of "Lubhang Napakabisa" as assessed by parents which is in contrary 
with the assessment of the pupil respondents. The same item got the lowest weighted mean of 3.93 and a verbal interpretation of "Napakabisa" as assessed by the pupil respondents. On the other hand, the item "pagbabayad ng authorized contribution at iba pang bayarin sa paaralan sa tamang panahon" got the lowest weighted mean of 4.35 and a verbal interpretation of "Lubhang Napakabisa" as assessed by the parents.It can be reflected on the results the different views of pupil and parent respondents on the effectiveness of the program in their education.

Their views can be attributed to the different roles and experiences they have. Pupil respondents were very curious if their parents are paying their authorized contribution because every month a DSWD representative and parent leader are monitoring the school head and advisers if the pupil recipients are paid in their authorized contribution and other financial obligations. If the pupil recipients are always reminded by the teacher to pay their authorized contribution, they see its importance, so pupils perceive "pagbibigay ng Php300 kada isang mag-aaral kada buwan" as the most effective in terms of education. Thus, some of the pupils did not pay their authorized contribution on time. While parent respondents believed that it was important that their child was attending school. They sometimes just sent their children to school without knowing that their children need to pay a certain amount from their authorized contribution every month. Like paying for school paper and athletics in the month of September and October is one of the obligations they need to follow. Some parents just pay authorized contributions at the end of the school year.

Based on the interview to some parent recipients, paying the authorized contribution on time is somehow hard for them since they sometimes shared the cash grant to their other children who are not 4P's recipients, so they perceived that "pagtugon sa authorized contribution at iba pang bayarin sa paaralan sa tamang panahon" is the lowest weighted mean. Social Welfare and Development Secretary Corazon Juliano Soliman said that the children of poor families are now enjoying better and improving access to education and better health services through the Pantawid Pamilya program. Aside from the government's aim of reducing poverty, the Pantawid Pamilya program also ensures that no one gets left behind in terms of achieving holistic and inclusive growth. However, some teachers said that pupils did not comply with the requirements in school. One of the respondents claimed that the budget for contributions and projects are spent on other expenses, like gambling and hard liquor.

\section{Table 2}

Constraints encountered by the respondents on the effectiveness of Pantawid Pamilyang Pilipino program

\begin{tabular}{|c|c|c|c|c|c|c|}
\hline \multirow{2}{*}{$\begin{array}{c}\text { Item } \\
\begin{array}{c}\text { Ang mga magulang at mag-aaral ay nakararanas ng } \\
\text { suliranin sa.... }\end{array}\end{array}$} & \multicolumn{3}{|c|}{ Pupils } & \multicolumn{3}{|c|}{ Parents } \\
\hline & WM & VI & $\mathrm{R}$ & WM & VI & $\mathrm{R}$ \\
\hline $\begin{array}{l}\text { 1. pag-unawa sa mga obligasyon, tungkulin at kondisyon } \\
\text { na dapat sundin sa programa }\end{array}$ & 3.36 & $\mathrm{MN}$ & 1 & 2.24 & $\mathrm{BN}$ & 1 \\
\hline $\begin{array}{l}\text { 2. pagdalo sa mga pagpupulong, gawain sa barangay at } \\
\text { Family Development Session (FDS) }\end{array}$ & 2.98 & PMN & 2 & 1.94 & $\mathrm{BN}$ & 3 \\
\hline 3. pagpasok sa klase ng mga mag-aaral & 2.43 & $\mathrm{BN}$ & 6 & 1.86 & $\mathrm{BN}$ & 5.5 \\
\hline $\begin{array}{l}\text { 4. buwanang pagpapatingin sa health center ng mga } \\
\text { buntis at mga batang may ay edad } 0-5\end{array}$ & 2.54 & $\mathrm{BN}$ & 3.5 & 1.92 & $\mathrm{BN}$ & 4 \\
\hline 5. pagsuporta at pagtulong mula sa mga parent leader & 2.10 & $\mathrm{BN}$ & 10 & 1.83 & $\mathrm{BN}$ & 8.5 \\
\hline $\begin{array}{l}\text { 6. paggamit ng ATM sa pagwidraw ng buwanang } \\
\text { benepisyo }\end{array}$ & 2.20 & $\mathrm{BN}$ & 9 & 1.86 & $\mathrm{BN}$ & 5.5 \\
\hline $\begin{array}{l}\text { 7. pagtugon ng 4P's Grievance Redress System sa mga } \\
\text { suliranin ng bawat benepisyaryo }\end{array}$ & 2.35 & $\mathrm{BN}$ & 7 & 1.99 & $\mathrm{BN}$ & 2 \\
\hline $\begin{array}{l}\text { 8. pagtanggap ng buong halaga upang matugunan ang } \\
\text { pangangailangan sa kalusugan/nutrisyon at edukasyon }\end{array}$ & 2.45 & $\mathrm{BN}$ & 5 & 1.84 & $\mathrm{BN}$ & 7 \\
\hline $\begin{array}{l}\text { 9. pantay na pagtingin o pagtrato sa mga benepisyaryo sa } \\
\text { paaralan at sa komunidad }\end{array}$ & 2.54 & $\mathrm{BN}$ & 3.5 & 1.72 & $\mathrm{HN}$ & 10 \\
\hline $\begin{array}{l}\text { 10. suplay sa gamot at kagamitan sa health center upang } \\
\text { tugunan ang pangangailangang medikal ng bawat } \\
\text { benepisyaryo }\end{array}$ & 2.25 & $\mathrm{BN}$ & 8 & 1.83 & $\mathrm{BN}$ & 8.5 \\
\hline Composite Mean & 2.52 & $\mathrm{BN}$ & & 1.90 & $\mathrm{BN}$ & \\
\hline
\end{tabular}


Table 2 shows the perceived constraints encountered by the respondents that may hamper the effectiveness of the Pantawid Pamilyang Pilipino Program. As reflected on the table, the item "kakulangan sa pag-unawa sa mga obligasyon, tungkulin at kondisyon na dapat sundin sa programa" got the highest weighted mean of 3.36 with a verbal interpretation of "Malimit Nararanasan" as perceived by the student-respondents. The same item got the highest weighted mean of 2.24 and a verbal interpretation of "Bihirang Nararanasan" as perceived by the parent-respondents. However, the item "kakulangan sa suporta at tulong mula sa mga parent leader" got the lowest weighted mean of 2.10 with a verbal interpretation of "Bihirang Nararanasan" as perceived by the student-respondents while the item "hindi pantay na pagtingin sa mga benepisyaryo sa paaralan at komunidad" got the lowest weighted mean of 1.72 and a verbal interpretation of "Hindi Nararanasan" as perceived by the parent-respondents.

These results can be explained by the fact that DSWD (Rosario) attested that some new household recipients are not aware of the overall obligations and responsibilities of Pantawid Pamilyang Pilipino Program; this constraint is visible through conducting Family Development Sessions (FDS). Some of the barangays did not attain the target parents' attendance of 95\%. Through this, all queries and concerns can be discussed. If parents are not attending, they will not understand the program. Therefore, "kakulangan sa pag-unawa sa mga obligasyon, tungkulin at kondisyon na dapat sundin sa programa" got the highest weighted mean for parent recipients.

According to the recommendation of the Magazine Business Week Mindanao (2013), there should be a regular follow-up if delisting of some beneficiaries is necessary because there might be some who are no longer qualified under the requirements given in the program. Some members also do not follow the conditions stipulated by the agency. Thus, the need to revitalize a "Grievance Committee" for a more responsive, appropriate, and timely solution to the problems encountered.

Table 3

Test of significant difference on the assessment of effectiveness of Pantawid Pamilyang Pilipino program

\begin{tabular}{lccccc}
\hline \multicolumn{1}{c}{ Category } & $\begin{array}{c}\text { Weighted Mean } \\
\text { Parents }\end{array}$ & $\begin{array}{c}\text { Weighted Mean } \\
\text { Pupils }\end{array}$ & $t$-value & $p$-value & Interpretation \\
\hline Health/Nutritional Welfare & 4.45 & 4.26 & 4.374 & 0.000 & Highly significant \\
Educational Welfare & 4.42 & 4.09 & 7.048 & 0.000 & Highly Significant \\
\hline
\end{tabular}

Table 3 presents the difference in the assessment of the student-respondents and parent-respondents regarding the effectiveness of the Pantawid Pamilyang Pilipino Program. Using t-test for independent sample means to find the significant difference; the equality of variances was used since there is a normal distribution of data.

As reflected on the table, the assessment of the student-respondents and parent-respondents differ from each other as conveyed by the t-value of 4.374 and p-value of 0.000 . Since the p-value obtained is less than 0.05 and 0.01 , it is therefore safe to conclude that there is a high significant difference on the assessment of the student-respondents and parent-respondents on the health/nutrition welfare brought by the Pantawid Pamilyang Pilipino Program. Similarly, the p-value obtained when a test of significant difference was used between the assessment of the respondents on the educational welfare of Pantawid ng Pamilyang Pilipino Program is less than 0.05 and 0.01 , thus rejecting the null hypothesis. It is therefore safe to conclude that there is a high significant difference in the assessment of the respondents regarding the educational welfare of the said program. This is possible since the parents are older than the children, thus the experiences of life affect the perspective of parents. Due to the responsibility of feeding not only the children covered by 4Ps, parents are depending on monetary help of the program, rather than the non-monetary benefit of it.

On the other hand, students are more focused and interested in educating them about health and nutrition since they are younger and do not have the responsibility like those of parents. Some of the basis of pupil respondent's perception relies on their observation of their parents but the perception of parent respondents is 
based on their own experiences. Moreover, not all families are directly experiencing the same problems. If in case, parents are in direct communication with their parent leader and coordinator, pupils are not. Through Grievance Redress Committee, parents are addressed to follow the conditions that the program gives. If parents cannot follow, pupils' welfare will be sacrificed too. With regards to the educational welfare of pupils, parents and pupil respondents have different views. Parents are highly confident now that their children will finish their education because all pupil- recipients are enrolled in school and getting financial assistance regularly.

Pupil recipients perceived the importance of the program because they are receiving a cash grant for education that is really a great help to their parents. Pupils see that their parents are at ease now unlike before since they are expecting regular cash grants. Moreover, GMA News Online (2013) published that school enrolment in 4P families was significantly higher for children aged 13 and above. This means that, as children from beneficiary families become eligible for cash transfers, there is an incentive for them to continue schooling. Indeed, according to Philippine Collegian Organization (2011), there is no context for the success of the program; even if every Filipino child goes to school every day, there is no way for him to receive a proper education. Schools throughout the country are overcrowded and underfunded, with too few rooms, teachers, schoolbooks, and funds.

Based on the findings of the study, different policy improvements were generated and proposed. To expand the number of children recipients per households to avoid insufficient cash grant, conduct and monitor monthly re-orientation, forums of parents and Family Development Sessions (FDS), implement delisting rule for those recipients that are not following the conditions of the program and set under-agencies that will conduct specific rules like deworming are some of the improvements for the implementation of Pantawid Pamilyang Pilipino Program (4P's). The Department of Education (DepEd) needs to permit the list of authorized contributions to be paid by parents and strictly implement the "No Collection Policy" in public education to make an effective program for the welfare of the pupil recipients.

\section{Conclusion/Recommendation}

From the findings of the study, the following conclusions were drawn.

1. Pantawid Pamilyang Pilipino Program (4P's) was very effective in improving the health and nutrition of pupil recipients. Features of Pantawid Pamilyang Pilipino Program (4P's) in improving the educational welfare of pupils were very effective according to the parents and pupils while other features are effective.

2. Pupil and parent respondents had problems in the implementation of Pantawid Pamilyang Pilipino Program (4P's) that they sometimes encountered.

3. There was a high significant difference among the assessment of pupils and parents regarding the effectiveness of the program on the education and welfare of the pupils.

4. There was a high significant difference among the assessment of respondents regarding the effectiveness of the program on the education and welfare of the pupils.

5. There was a high significant relationship between the effectiveness of Pantawid Pamilyang Pilipino Program (4P's) and constraints encountered by the pupil and parents.

6. Different policy improvement was proposed to enhance the education and welfare of pupil recipients in Rosario, Batangas.

Based on the analysis, interpretations and conclusions of the study, the following are the recommendations.

1. Department of Social Welfare and Development (DSWD) should enhance the Pantawid Pamilyang Pilipino Program (4P's) in terms of health/nutrition and education for the benefit of pupil recipients through strictly reinforce program in attending Family Development Sessions (FDS) by reporting to the

142 Consortia Academia Publishing (A partner of Network of Professional Researchers and Educators) 
Grievance Redress Committee any violation and ground them for delisting, and monitoring if all children aged 3-18 are in school by coordinating to the focal persons in the school.

2. DSWD should strictly enforce and monitor the program to let all household recipients understand the obligations, responsibilities, and conditions of 4P's through rigid checking of every parent leader in each barangay if all members are following the conditions under the program. For the old and new recipients of the program, they must undergo orientation about the conditions of the program.

3. The Department of Social Welfare and Development must increase the cash grants for educational welfare of pupil recipients and control the family educational expenditure by coordinating with the teachers if they are paying financial obligations in school and make sure that all pupil recipients are attending school not just for attaining the attendance rate of DSWD but for gaining knowledge. Since parents and pupils have different assessments regarding the effectiveness of the program, parents must explain to their children about the environment of the program.

4. Local government of Rosario through DSWD must conduct a mass orientation for each household recipient and responsive help desks that will answer different problems encountered by the recipients.

5. To make the program more effective for the benefit of the pupils, the problems encountered by the recipients must be solved by sending different appointed persons and under-agencies that will take immediate actions.

6. The government through the Local Government Units shall design policy improvement on how to enhance the education and welfare of pupils recipients in Rosario, Batangas like: expanding the number of children recipients per households to avoid insufficient cash grant, conducting and monitoring monthly re-orientation, forums of parents and Family Development Sessions (FDS), implement delisting rule for those recipients that are not following the conditions of the program and set under-agencies that will conduct specific rules like deworming. The Department of Education (DepEd) must approve the list of authorized contributions to be paid by parents and strictly implement the "No Collection Policy" in public education.

\section{References}

Amigo, J. D. (1995). Families and school together. North Central Regional Educational Laboratory, 27-30.

Barrientos, A. (2001). Cash transfer literature review department of national development. UKAID.

Dammert, A. C. (2008). Heterogeneous impacts of conditional cash transfers: Evidence from Nicaragua. https://doi.org/10.1086/605205

Identifying beneficiaries of conditional cash transfer programs. (2012) Retrieved February 22, 2012, from http://www.chronicpoverty.org/uploads/publication_files/azevedo_robles_multidimensional

Observations of the Pantawid Pamilyang Pilipino Program in the field. (2013). AusAID in coordination with DSWD. World Bank, and ADB.

Pantawid Pamilyang Pilipino Program (4P's). (2015). Official Gazette.

Sansone, F. A. (2015). The sociology and social welfare (pp. 201-207).

Social protection for the poorest: Taking a broader view in poverty in focus. International Poverty Centre. (2011). United Nations Development Program. Retrieved January 3, 2011, from http://www.ipc-undp.org/pub/IPCPovertyInFocus8

The Politics of Conditional Cash Transfers of the Philippines. (2007). International Institute of Social Studies, Philippines.

The short-term impact of a conditional cash subsidy on child health and nutrition in Colombia. (2005).

Centre for the Evaluation of Development Policies. Retrieved from

http://www.ifs.org.uk/edepo/rs_fam03.pdf 
Ramos, A. D.

144 Consortia Academia Publishing (A partner of Network of Professional Researchers and Educators) 